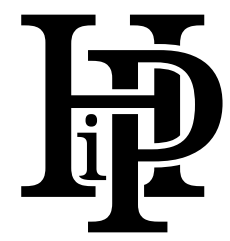

\author{
Robert ŁOŚ
}

University of Łódź, Faculty of International and Political Studies, Poland

\title{
Russia's Soft Power
}

\author{
Soft power Rosji
}

\section{- Abstract •}

Russia has always been a country seeking the Great Power status. Even though it lost its importance after the collapse of the Soviet Union, the desire to return to the role of the creator of international order forces it to introduce new strategy that will implement soft power resources. This represents a certain obstacle for Russia, which traditionally is accustomed to hard power resources like economic pressure or the use of armed forces. Culture is Russia's soft power resource that is significant. Values can be more problematic for Russia, because in Moscow's intentions they should be different from the Western values. Russia is trying to create an alternative soft power project, competitive to that of the West. Russia is trying to make good use of its diplomacy, including digital diplomacy, in order to show the use of its hard power to be seen as soft.

Keywords: Russian soft power; resources; public diplomacy

\section{- Abstrakt •}

Rosja zawsze była państwem o ambicjach mocarstwowych. Rozpad ZSRR oznaczał utratę takiej pozycji, a chęć powrotu do statusu mocarstwa światowego wymusza wypracowanie nowej strategii, która przewiduje użycie środków soft power. Stanowi to pewną trudność dla Rosji, nawykłej do tradycyjnego wykorzystywania zasobów kojarzonych z hard power, takich jak presja ekonomiczna czy użycie sił zbrojnych. Znaczącym zasobem rosyjskiej soft power jest kultura. Natomiast bardziej problematyczne mogą okazać się wartości, ponieważ w intencjach Moskwy powinny one różnić się od wartości zachodnich. Rosja stara się więc stworzyć alternatywny projekt soft power, konkurencyjny wobec Zachodu. Sprawnie prowadzona dyplomacja, w tym dyplomacja cyfrowa, służy takiemu przedstawianiu wykorzystywania środków hard power, by mogły one uchodzić za elementy soft power.

Słowa kluczowe: rosyjska soft power; zasoby; dyplomacja publiczna 


\section{Introduction}

The aim of the article is to determine Russia's soft power and its potential use for the growth of a state's power. For the purpose of the article, it is necessary to assume that power is a state's hypothetical potential to utilise its material and non-material resources in order to exert its will irrespective of other participants' objections or interaction. Force refers to a state utilising material and non-material resources, mobilised under definite conditions, in order to exert its will irrespective of other participants' objections or interaction (Moczulski, 1999; Sułek, 2001). Therefore, force is action or influence, not a hypothetical possibility, and its magnitude depends on its suitability at a given time and place.

There is a rich literature on the issue of soft power in its broad meaning. A considerable part of the publications, which have been referred to, belongs in the canon of sciences about international relations. Among them there are the works by H. Morgenthau, R. Keohane, J. Mearsheimer, K. Waltz, W.R. Meade. E. Carr, K. Knorr, R.S. Cline, T. Friedman, A. Giddens, H. Kissinger, R.A. Dahl, K. Boulding, C.S. Gray, J.S. Nye, N. Ferguson, R. Cooper, J. Kurlantzick, R. Kagan, F. Zakaria, G.J. Ikenberry (Łoś, 2017).

The concept of 'soft power' was noticed and applied by Joseph Nye, Jr. in his book entitled Bound to Lead: The Changing Nature of American Power (Nye, 1991). He then used the concept in further publications (Nye, 2002; 2005; 2007; 2011). While introducing the term 'soft power' into the terminology of international relations, J. Nye described it as the ability to shape others' preferences thanks to attractiveness and attraction by means of possessed resources, in which he included culture, values and the style of conducting foreign policy.

Supporters of soft power have imposed many restrictions on the term and boundaries of its applicability, which only proves how difficult it is to determine universal rules, methods and verifiable research results (Nye, 2007). In the process of defining soft power, resources should be separated from applied instruments which to a great extent determine the classification of power. Diagram 1 allows to determine categories of power and link them to the instruments. Applied tools determine the classification of power and, in practice, it is possible to use any resource to generate soft interaction, in a suitable proportion. However, it must be emphasised that the division does not translate into their actual influence.

Therefore, one may assume that soft power is connected with elements of culture, value of education, efficiency of state institutions and diplomacy. It also includes some elements of economy such as innovativeness and participation in creating and operating extensive structures and social-political norms. Including part 
of economic tools in the soft power category is based on the principle that economy supports every kind of a state's power. A state which creates conditions for economic development through the scope of freedom not only in the area of economy, supports soft power. The military aspect should also be taken into account in the process of building soft power. Military forces may be helpful in supporting soft power on condition that the influence is restricted to gaining admiration or providing assistance in natural disaster situations.

In Russia the term 'soft power' has been translated as soft force, authority, superpower or flexible power (Łoś, 2017).

\section{Culture and Values}

The debate about Russia's culture concerns the problems centred on the slogans "Russia - The Soul of the World" and "Moscow - The Third Rome", and this may cause Russia to have difficulty in adapting to the contemporary world (Broda, 2011, p. 212). The issue of an unfathomable Russian soul is willingly stressed, which unfortunately leads to creating stereotypes, which Russians find it hard to free themselves from. That is why Russians are convinced that others assess them in the context of negative stereotypes, traditional perceptions, deterministic nature of history and conviction of the unique nature of Russian lot. To a large extent, this uniqueness stems from the conviction that Russia is a closed culture and interest in it is restricted to a clearly defined group (Lazari, 1996). In patriotic publications, there appears a spirit of rejecting Western civilisational solutions as inconsistent with the Russian nature. In this context, the West is an eternal enemy of Russia, aiming at building one world civilisation and desiring to annihilate Moscow in the name of the world order (Wyciszkiewicz, 2003).

The years of co-existence in one state such as the Russian Empire and the Soviet Union have naturally produced linguistic ties. It is hard to unambiguously determine the link between an origin and a language. For historical reasons, the choice of a language depends more on a region of inhabitance than on an origin. Both of these factors demonstrate that a language is not a determinant of a political affiliation. After more than 20 years from gaining independence, the language borders between nations have been changed, but the circle of people using regional languages has expanded. Nonetheless, the Russian language still has a chance to become the lingua franca of the area of the Commonwealth of Independent States, which can help the Russian Federation promote culture, tradition or values. In order to popularise the Russian language, Russia relies on numerous Rus- 
sian and Russian-speaking population, living in the former Soviet Republics. They constitute a natural vehicle for spreading Russian values, traditions, customs and language.

Values, which can differentiate Russia from the West, are another element influencing soft power. Political values, such as democracy or human rights, can be another strong source of attraction to Russia, but declarations about these values do not suffice; their implementation and adhering to them are required. Russia could not compete with the West in these respects. It would be even more important due to the fact that the activities of the Western states attract and convince many countries. The ideology of the West convinces a group of these countries, especially because Russia has been lacking in this ideology. Being aware of such ideological vacuum, Russian leaders filled it in with a concept of a sovereign democracy, different from the one offered by the West.

Independently of the new Russian concept of the sovereign democracy, the $19^{\text {th }}$ century Euro-Asian concept is constantly revived in the scientific and artistic circles. Its proponents advocate a "multipolar" world order, in which, in their opinion, multiple centres of power will balance one another and provide security. Such an order also gives Russia a chance of playing the role of a leader of one of such influence poles. According to the Euro-Asian concept advocates, Russia's unique geopolitical position on the Eurasia landmass enables it to be a connector between the two worlds and the two civilisations (Arutunyan, 2013). This specificity, together with its separation (also historic) from the Western civilisation, determines, according to the Euro-Asian concept proponents, the selection of an alternative for the development of the Russian state, which is called the Third Road.

Russia finds it difficult to shape values. Apart from those of the Third Rome and the Russian Orthodox Church, Russia faces systematic obstacles, preventing it from developing soft power. Russian consciousness still lacks conviction about the need to abide by the human rights or other laws, but not as tools of repressions or persecution (Broda, 2011). Even demonstrating power against the opposition strengthens the authorities, because thanks to it the citizens feel more certain that the authorities are in control of the situation in the country. The Russian society is convinced that a strong leader, who will stabilise their country, is necessary. Putin appears to suit the reality (Lucas, 2008) as he has introduced a system based on slightly different values instead of democratisation, which was associated with chaos, shortages and uncertainty (Avgerinos, 2009). 


\section{Foreign Policy as an Element of Soft Power}

Admittedly, Russia seems to have difficulty in utilising soft power even if there exist appropriate resources for this purpose. Occasionally, power play or building relations based on fear seem to be a faster way to reach the goal but they demonstrate that Russia's foreign policy lacks efficiency (Buras, 2008). Russia possesses soft power resources but it lacks skills or a distinctive, attractive cultural project, which prevents it from adapting and functioning by using the soft power formula (Podliesnyj, 2004).

The Russian Federation's foreign policy successfully utilises economic and military tools, which demonstrates its tough stance in accordance with the nature of these methods. Utilising various methods on the basis of more subtle soft power techniques requires slightly more effort. Shortly after the dissolution of the Soviet Union Russia had absolutely no possibility of doing that. Initially, Boris Yeltsin embraced the rules of the European countries and Kremlin's policies were pro-European (Włodkowska, 2006).

The change of the policy took place gradually. In his address in 1996, President Yeltsin strongly emphasised that NATO's expansion to the East should be prevented. The period of 1997-2000 marks the beginning of W. Putin's era, who already, as the Prime Minister, approved the new guidelines for foreign policy (in 2000). 2001 was a transitory period, which was connected with the $9 / 11$ terrorist attack. In this period the USA and the European Union came to an agreement. It appeared that Russia was necessary to control Iran, the Middle East, Afghanistan, and North Korea. The relationships worsened at the turn of 2003 and 2004, during the war in Iraq, and in the next few years the conflict aggravated due to the invasion of Georgia and Ukraine.

In July 2008, after Dimitry Medvedev became President, the guidelines of the Russian Federation's foreign policy were approved (2009). They stated that guaranteeing security and reinforcing sovereignty and territorial integrity are of the utmost importance. Russia recognised the expansion of NATO by Ukraine and Georgia as one of the threats. In this duet, Georgia was in conflict with Russia, but it was Ukraine that was pivotal (Potocki, 2009). The necessity to create external conditions conducive of Russia's development were next in line. In order to achieve this goal the process of resolving problems was to be enhanced by applying international law, the UNO's mediation; establishing good neighbourly relations by liquidation of threats; comprehensive defence of borders; collaboration for enhancing the perception of Russia in the world as a democratic state with socially-oriented mar- 
ket economy and with independent foreign policy; supporting and popularisation of the Russian language and the cultures of the nations of Russia, which uniquely contribute to the cultural and civilisational diversity of the contemporary world and to the development of the partnership of civilisations (Czajkowski, 2011).

The propositions comprised in the guidelines clearly refer to soft power, whose tools could strengthen the Russian Federation's position. In 2013, the new "Concept of the Foreign Policy of the Russian Federation" emphasised the need of international cooperation and strengthening Russia's position by developing the knowledge of Russian, activating public diplomacy, digital diplomacy, education and culture (Concept..., 2013). All these activities were to contribute to "the objective perception of Russia in the world", gaining understanding and support for its policy (Lukyanov, 2013; Nye, 2013).

Nevertheless, this form of utilising soft power tools is limited by undemocratic nature of power in Russia, rather unpleasant perception of the external environment ('besieged fortress' syndrome) and separation of elites from the society. As a result, citizens find it difficult or even impossible to gain insight into the operation of state institutions and influence decision-making processes. It also restricts personalisation of accounts and discussion in social-network services. Moreover, Russia does not use its full potential. Russian authorities make little effort to cooperate with the Internet community which, by means of civic diplomacy, could complement the state's activities focused on creating Russia's image in the world. It has changed since new goals were created, e.g., Crimea and East Ukraine.

The analysis of the Russian Federation's activities on the international arena, especially in the area of the former Soviet Union, leaves the impression that it was only recently that Russia began to notice soft power means of influence and value their role. Immediately after the dissolution of the Soviet Union, first Russia had to reject its paternalism and build good relations with the former Soviet republics based on the new principles of partnership. Russia, especially in its actions towards the "near abroad", utilises a broad range of various means, from political and military ones to economic, cultural and ideological ones. Throughout the 1990s, Russia most rarely resorted to the latter ones. That is why Russian military assistance or Russia's engagement in peace-keeping operations in the area of the Commonwealth of Independent States as well as supporting party groups outside Russia, which approve of Moscow's policy, were noticeable.

Other options in the economic aspect are created by developmental assistance. Russia provides assistance to developing countries, allocating only USD $500 \mathrm{~m}$ a year, i.e., 0,03\% of Russia's GDP. It is not much but Russia provides this kind 
of assistance consistently, mainly in the CIS area. Russian developmental assistance is aimed at executing specific projects in exchange for these states' support (OECD Factbook, 2018-2019).

Russia's profuse utilisation of power and emphasising its own interests discouraged the CIS states and made it difficult for the Russian Federation to achieve its main goal, i.e., attaching all the former Soviet republics to itself. Due to the little effectiveness of military resources, it moved from them towards a more balanced and pragmatic policy. The Russian Federation realised that military power might evoke respect, but not attraction.

Poor ability to construct a new order and the system's weak potential to change influences were the weaknesses of the Russian Federation's foreign policy. It was important as the beginning of the $21^{\text {st }}$ century surprised Russia with the so-called "colour revolutions", which undermined its position in the CIS region. Especially the Ukrainian revolution in 2004, and later the Euromaidan, made Russian decision-makers introduce changes. Moreover, the process of the European integration, regardless of internal and external criticism of it, poses a great challenge to Russia. Integrating Europe is a big competitor for Russia, especially in case of the post-Soviet neighbours of the EU, who declare their will to access this institution and the mechanisms run from Brussels in their attempt to gain support for building their national organisms. For Russia and its activities in the post-Soviet area, the relations with the European Union posed a threat. If it wanted to avoid ostracism, using soft power tools was the only solution.

In this situation, it is significant for Russia to find its place in the new international order. It was and it is of utmost importance to look for an alternative to the West in Asia. In this way, Russia did not leave itself any space for manoeuvre and it seemed that it had no other option than searching for some agreement with China. In 1996 mutual relations were called "strategic partnership". A few years later, in 2001, the pact for friendship and cooperation was signed. This partnership rests on the common opposition to the contemporary world dominated by the USA (Nye, 2011). The alliance was called the pillars of the www (the World Without the West) agreement, which can be achieved by utilising the potential of soft power. Russia and the PRC have divergent views of the world, different attitudes to foreign policy, and sometimes conflicting priorities. Nonetheless, the PRC is interested in good relations with Russia if it wants to become the world's leader. 


\section{Instruments of Soft Power}

What fosters the development of the Russian soft power are various historically shaped phenomena harking back to Russia's past. Its numerous diaspora and common language constitute advantageous elements (Sherr, 2013). The post-Soviet countries' political system is also characterised by an enormous number of small and weak political parties, which are susceptible to Russian influence. Business interests represent further important factors. Many local groups, as well as business ones, become involved in politics and finances of post-Soviet states in favour of Russia (Olszański, 2014; Wierzbowska-Miazga \& Sarna, 2014).

The Russian Orthodox Church constitutes not only a significant element of culture, but also a tool of exercising authority. The Church in Russia claims to be unique, and constitutes an authority for the only true faith, giving a moral and spiritual sanction for power secured by the authorities. The notion of Moscow supposedly being the Third Rome, the heir to the imperial, cultural and spiritual mission of the ancient Romans and the Byzantine Empire, reflects this opinion. That is why the authority in Russia often invokes religious arguments and utilises the support of the Church in carrying out their projects (Blitt, 2021; Akturk, 2019).

How strong is the role of the language in soft power can be demonstrated by the fact that on November 4, 2007, on the Unity Day, President Vladimir Putin declared 2007 the Year of the Russian Language. The goal of this project was to increase the interest of the rest of the world in the language and culture of Russia, as well as popularising a positive image of this country. Many cultural events, exhibitions, presentations, conferences and competitions were planned. Going further in determining cultural tools, the authorities announced their plan to establish a western-style cultural institution. Then, on June 21, 2007, a Presidential Decree established the "Russkij mir" Foundation, whose main goal is to popularise the Russian language and culture. The Foundation cooperates with the Ministries of Foreign Affairs and of Education and Science, which enabled it to create culture centres in 39 countries (Russkiymir, 2019). The Foundation is to be a supplement for the Russian Institute, which has existed in the national structures since 1996 (Lazari, 1996).

An artful utilisation of the Russian language in cultural policy can bring many benefits. The popularisation of Russian literature, cinema and music, opening schools teaching the Russian language and Russian culture institutes in individual countries could assist in creating a positive image of Russia. Through teaching Russian, the image of Russia can also be created among children and teenagers, that is this part of the society which in the future will make decisions (Włodkowska- 
-Bagan, 2012). With children and teenagers in mind, Russia launched the programme "Welcome, Russia", whose goal is to maintain and reinforce the ties between the homeland and the young compatriots living in the countries from the "near abroad".

In September 2008, President Medvedev signed the decree reorganising the Federal Agency for the Commonwealth of Independent States (WłodkowskaBagan, 2012). These changes were aimed at the centralisation of actions allowing Russia to maintain its influences within the Commonwealth of Independent States and to build a friendly climate for fulfilling Russia's political and economic interests. The new institution took over the competences of a few structures operating on the international cultural platform. Its tasks included preparing a coherent programme line of a widely-understood international cooperation, among other things, through setting up a programme of assistance for the CIS countries.

Furthermore, in 2010, the Alexander Gorczakov Public Diplomacy Fund was established and in 2012, the Foundation of Historical Memory was created (historyfoundation.ru). The Foundation is referred to as a non-governmental organisation, however, it strictly follows Kremlin's guidelines. Its activities reflect the authorities' efforts to utilise Russian soft power resources. Nevertheless, Russian culture is still not fully utilised. It is widely known and respected worldwide, being a product of various cultures of the nations living on the territory of this gigantic country throughout centuries and whose cultural works were treated as Soviet over a few decades. The names of the authors of the well-known artistic and literary works belong to the canon of great world literature (Leo Tolstoy, Alexander Pushkin, Fyodor Dostoyevsky, Nikolai Gogol, Mikhail Bulgakov) and music (Pyotr Tchaikovsky, Sergei Rachmaninoff, Igor Stravinsky, Dmitri Shostakovich). Russian museums and scientists (Dmitri Mendeleev, Sergei Korolev) are also widely appreciated.

Russian high culture exists side by side with Russian pop culture, which has influence not only in the CIS countries, but also on the international scale. Using soft power by the Russian Federation in its policy towards the "near abroad" is also connected with the support for Russian theatres and cinemas. The emphasis placed on the popularisation of the Russian cinema can be noticed within all the Commonwealth of Independent States. Moreover, it is present at various film festivals. The screenings of Russian films are very important due to the fact that the cinemas in the CIS countries are flooded by Western productions. Russian war films constitute a considerable number of films screened in many CIS states (Łoś, 2017).

Russia also has prize-winning sportsmen and sportswomen who are its symbols in the world (Łoś, 2017). It is important, since sport, as is the case with cinema, is 
a major element of mass culture. Especially tennis players such as Elena Dementieva, Maria Sharapova or Marat Safin are well-known and admired Russian sportspeople. Anna Kurnikova even became the face of pop culture, frequently featured in tabloids. The pole-vaulters Yelena Isinbayeva and Svetlana Feofanova are also commonly known. Apart from that, the Russians have won the top positions in figure skating and have one of the best ice-hockey leagues in the world: Continental Hockey League. Additionally, some teams from the Commonwealth of Independent States are sponsored by the Russian companies, for example, Latvian group Dinamo Riga is sponsored by Itera (gas distributing company). Moreover, many players prefer to play for Russian teams, where they receive better remuneration.

Sports events are equally crucial. These were Light Athletics World Championships in Moscow (2013), the Olympic Games in Sochi (2014), and the Football World Championships in 2018 appears to be equally important. They can draw the world's attention to Russia, which will use this opportunity for marketing purposes, which in turn enables it to support its own options in foreign policy. Unfortunately, these achievements have been overshadowed by the doping affair.

Russia also contributes significantly to the world of science, which is demonstrated by the number of the Nobel Prize winners although this count is not very impressive. Higher education constitutes a significant element of soft power, as it helps to form future foreign economic, political and military elites benevolent to the state which assisted in their education. The institutions of higher education comprise the part of the network of transnational influences and they can share the same values (Arefjev, 2006). According to the UNESCO statistical data from 2016, over 170 thousand foreign students attended university courses in Russia, $30 \%$ of whom came from the former Soviet Republics (ISCED, 2015). The number of students from the former Soviet Republics studying at Russian universities and colleges and their foreign faculties and branches is increasing. Lomonosov Moscow State University decided to open its branches in Uzbekistan (in Tashkent), Kazakhstan (in Astana), Ukraine (in Sevastopol), and from 2009 in Tajikistan (in Dushanbe) and Azerbaijan (in Baku). Opening the university branches in the countries of the "near abroad" helps to educate a future cadre and directly influences the image of Russia among young people, especially because Lomonosov University enjoys good reputation (Włodkowska, 2006). Despite the development of its educational offer, Russia is not able to compete with broadly understood Western states.

In order to successfully utilise soft power tools, Russia must develop non-governmental organisations. Those which were set up after the dissolution of the Soviet Union are supported by international networks and as such they are exceptionally closely scrutinised by the authorities. Kremlin did not see them as the support 
for building civil society, but rather as obstacles to carrying out its own policies. They should have been disposed of and the new ones, which would be controlled by Kremlin, should be established (Lucas, 2008).

\section{Media}

The media are an important tool enabling the utilisation of soft power by Russia. Russian stations, press, and the Internet websites are a significant element in disseminating information in the circles which are mainly focused on the Russian culture. Russian TV news programmes have a political dimension and their detailed news reports are full of vagueness, doubts and half-truths. Russian media are completely dependent on Kremlin, which makes it possible to maintain consistency of interpreting events. The Russian information network comprises a great media concern - Russia Today (RT), The Voice of Russia radio station, All-Russia State Television and Radio Broadcasting Company, National Media Group and Gazprom Media Holding. The media platform comprises Sputnik. RIA Novosti news agency broadcasts to 45 countries, in 14 languages. RT broadcasts news and commentaries on what is going on in the world 24 hours a day. It is available in cable TVs, on satellites and on-line. It broadcasts in Russian, English, Arabic and Spanish and on the territory of the Commonwealth of Independent States the programmes are broadcast in the Russian language.

The impulse to reinforce the Russian presence in social media was given in July 2012 by President Vladimir Putin during his meeting with the diplomatic representatives of the Russian Federation. Then he said that the Russian opinions on many issues were not known well enough and they must be constantly presented and explained, also by means of new technologies. As a result, Russian institutions, as well as officials and politicians industriously began to create accounts in social media, especially non-Russian ones. Additionally, the new versions of the Internet websites of Russian offices were launched with more practical and clear graphic layouts and with more prominent links to their profiles in social media (Seib, 2012).

\section{Soft Power Ranking}

The interaction potential of Russian soft power is not substantial. To a large extent, it results from the understanding of this phenomenon, which translates into the practice of the execution of soft influence. Naturally, Russia is unable to achieve fa- 
vourable results instantly, which would demonstrate its increasingly important position. On regular basis soft power evaluation is conducted in a number of areas: diplomacy, social-political and social-economic category, education, popular and high culture (Łoś, 2017).

In diplomacy category President Putin, whose perseverance and "tough leader" approach are well-appreciated, has the best results (Roxburgh, 2012). He tops the list of the most influential people in the world. In other categories indicators place Russia on an average position, particularly in comparison to the states aspiring to gain or maintain a superpower position. Only better use of institutions responsible for promoting Russian culture abroad distinguishes it from others.

In social-political category Russia has the worst position. Both the scope of freedom and rights as well as the organisation of the state in Russia are appalling. Factors such as the scale of freedom assessed by Freedom House, free access to the Internet, freedom of the press place Russia far behind the world's leaders. As for freedom of the press Russia ranks 148 in the world, which demonstrates how the state is evaluated and whether there exists space for criticism and freedom of speech. It is confirmed by the fact that the regime in Russia has created a façade democracy, which has an adverse effect on the efficient management of the state. Factors associated with the rule of law, democratic liberties and efficient operation of Russia's institutions are even worse than those of the PRC.

In social-economic category the evaluation of Russia is slightly better. Among big companies only 3 out of 100 are recognisable in the world. The innovation factor places Russia at the $48^{\text {th }}$ position and the competitiveness factor, slightly better, at the $42^{\text {nd }}$ position. Also, Russia does not have outstanding achievements in the field of developmental assistance (the $21^{\text {st }}$ position with USD $700 \mathrm{~m}$ of annual assistance). Comfort of life (HDI) does not impress either, but due to the scale of the state it is not surprising (the $38^{\text {th }}$ position in the world). Russia also finds it difficult to manage social inequalities and the Gini coefficient places the state at the $87^{\text {th }}$ position in the world.

Education is not the strongest category of Russian soft power. The state does not have strong universities although they are among the best 30 . Universities accept a considerable number of foreign students, mainly from the area of the former Soviet Union. Russia's educational efficiency at lower levels is not impressive and the state ranks 19 in the world in this respect. Think tanks are of little influence and the number of the Nobel Prize winners in exact sciences is slightly disappointing, giving Russia the $9^{\text {th }}$ position in the world.

Russia performs best in popular and high culture category, however, its advantage over Western culture is due to its uniqueness and particular spirituality. Russia 
benefits from the promotion of the Russian language (the $6^{\text {th }}$ position in this category), making a great effort to maintain the language as dominant in the former Soviet Union Republics. The number of objects on the UNESCO list places Russia at the $6^{\text {th }}$ position and it ranks the $8^{\text {th }}$ in the world as for the number of the most frequently visited museums. The list of the Nobel Prize winners in literature is not impressive: Russians have won only 3 prizes so far, which gives them the $10^{\text {th }}$ position in the world. In tourism Russia ranks $9^{\text {th }}$ but it has the $2^{\text {nd }}$ position with respect to the number of Olympic medals. Music and cinema, with little exceptions, are not really Russia's speciality.

Table 1. Ranking of Selected States in Terms of Soft Power

\begin{tabular}{|c|c|c|}
\hline Ranking & State & Number of points (max. 60) \\
\hline 1 & USA & 49,50 \\
\hline 2 & Great Britain & 44,00 \\
\hline 3 & Germany & 40,50 \\
\hline 4 & France & 39,75 \\
\hline 5 & Sweden & 30,50 \\
\hline 6 & The Netherlands & 28,75 \\
\hline $7-8$ & Italy, Canada & 27,50 \\
\hline 9 & Denmark & 27,00 \\
\hline 10 & Finland & 25,75 \\
\hline 11 & Switzerland & 25,25 \\
\hline $12-13$ & Austria, Spain & 24,00 \\
\hline 14 & Japan & 23,50 \\
\hline 15 & China & 23,00 \\
\hline 16 & Australia & 22,50 \\
\hline 17 & Norway & 22,25 \\
\hline 18 & Belgium & 21,00 \\
\hline 19 & New Zealand & 20,00 \\
\hline 20 & The Czech Republic & 17,50 \\
\hline 21 & Poland & 16,75 \\
\hline $22-23$ & Ireland, South Korea & 15,25 \\
\hline 24 & Luxembourg & 14,00 \\
\hline 25 & Brazil & 12,00 \\
\hline $26-27$ & Iceland, Singapore & 10,75 \\
\hline
\end{tabular}


Tab. 1 - cont.

\begin{tabular}{|c|c|c|}
\hline Ranking & State & Number of points (max. 60) \\
\hline 28 & India & 10,00 \\
\hline $29-30$ & Portugal, Russia & 9,50 \\
\hline
\end{tabular}

Source: Łoś (2017, p. 243).

Taking all Russia's achievements regarding soft power into account, it ranks $30^{\text {th }}$ only. This is not an impressive result, but the scale of soft influence can be discussed in more detail after considering differences in individual categories.

Diagram 1. The Scope of Russia's Soft Power Potential According to Individual Categories

\section{Russia's soft power}

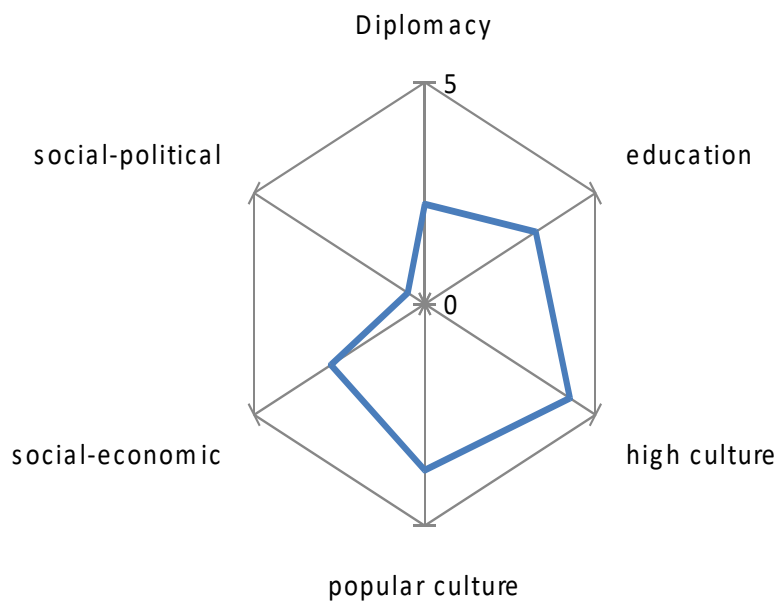

Source: Łoś (2017, p. 290). Each category is maximum 10 points.

Presented Russian model of soft power development is asymmetric. The lack of harmony presents little prospect for the development of soft power. This means that Russian authorities will have to apply many resources, inadequate to the expected results, in order to increase soft power. Therefore, it is expected that Russia will be more inclined to utilise hard power instruments in order to achieve its objectives. 


\section{Conclusions}

Russia is falling behind due to the lack of soft power. It is hard to unambiguously determine whether it is unable to develop soft power systematically or it has insufficient resources to achieve this goal. Both these elements certainly contribute to this state of affairs. Russia's soft power is burdened by the heritage of imperialism and communism. Both the empire of Tzars and the Russian empire were very oppressive, and as a result of this the utilisation of soft power is very doubtful. Nevertheless, Russia refers to Slavic traditions, fascination with the Russian soul and popularity of Russian culture in the West. It also uses symbolic terms, perceives itself as a custodian of the Orthodox Church tradition, and as the leader of Eastern Christianity.

Russian consciousness still lacks conviction about the need to abide by the human rights or other laws, but not as tools of repressions or persecution (Broda, 2011). Even demonstrating power against the opposition strengthens the authorities, because thanks to it the citizens feel more certain that the authorities are in control of the situation in the country (Lucas, 2008). Even if there exists a discrepancy between the declared values and the practice of implementing them by the system, it does not prevent Russians from judging the authorities regardless of it.

It is hard for Russia to create soft power through an apparent change of the style of foreign policy, and it is even harder to capture human hearts and minds by other means than power (Włodkowska, 2008). Noticeable steps have been taken in order to promote the Russian tradition abroad. These attempts reflect the synergy between the governments, semi-official foundations, favoured media, church and diaspora, so that soft power tools will be utilised in an appropriate way with a view to maintaining its influence in the territory of special significance to Russia. Nevertheless, political practice proves that Russia is more willing to utilise hard power tools in order to resolve potential conflicts.

\section{References:}

Akturk, S. (2019, November 11). Five Faces of Russia's Soft Power: Far Left, Far Right, Orthodox Christian, Russophone, and Ethnoreligious Networks. Retrieved from: https:// www.ponarseurasia.org/five-faces-of-russia-s-soft-power-far-left-far-right-orthodoxchristian-russophone-and-ethnoreligious-networks/.

Arefjev, A. (2006). Skolko ljudje govorjat i budut govorit po-russki. Demoskon Weekly, 251-252. Retrieved from: http://demoscope.ru/weekly/2006/0251/tema04.php. 
The Art Newspaper (2018). Retrieved from: https://www.readkong.com/page/art-s-mostpopular-exhibition-and-museum-visitor-figures-7100161.

Arutunyan, A. (2013). Car Putin. Feudalizm, korupcja i Bóg w państwie patrymonialnym. Poznań: Zysk i S-ka.

Avgerinos, K.P. (2009). Russia's Public Diplomacy Effort: What the Kremlin is Doing and Why It's Not Working. Journal of Public International Affairs, 20(1), 115-132. Retrieved from: http://www.princenton.edu/jpia/past-issues-1/2009/6.pdf.

Blitt, R.C. (2021, May 13). Religious Soft Power in Russian Foreign Policy: Constitutional Change and the Russian Orthodox Church. Retrieved from: https://berkleycenter. georgetown.edu/publications/religious-soft-power-in-russian-foreign-policy-constitutional-change-and-the-russian-orthodox-church.

Broda, M. (2011). „Zrozumieć Rosje”? O rosyjskiej zagadce-tajemnicy. Łódź: Wydawnictwo Naukowe Ibidem.

Buras, P. (2008). Między europeizacją a Gazpromem: Niemcy, Rosja i bezpieczeństwo energetyczne. „Raporty i analizy”, 7. Warszawa: Centrum Stosunków Międzynarodowych.

Concept of the Foreign Policy of the Russian Federation (2013, February 12). Ministry of Foreign Affairs (Russia). Retrieved April 1, 2013 from: http://www.mid.ru/brp_4. nsf/0/76389FEC168189ED44257B2E0039B16D.

Czajkowski, A. (2011). Federacja Rosyjska: przywracanie utraconej wielkości. In: T. ŁośNowak (Ed.). Polityka zagraniczna. Aktorzy, potencjaty, strategie (pp. 81-103). Warszawa: MT Biznes, Poltext.

Dolinsky, A. (2012, October 16). What is Public Diplomacy, and Why Russia Needs It. Russian International Affairs Council. Retrieved April 2, 2017 from: https://russiancouncil.ru/en/analytics-and-comments/analytics/what-is-public-diplomacy-and-whyrussia-needs-it/.

Grigas, A. (2012). Legacies, Coercion and Soft Power: Russian Influence in the Baltic States. Briefing Paper. Chatham House. Retrieved from: https://www.chathamhouse.org/ sites/default/files/public/Research/Russia\%20and\%20Eurasia/0812bp_grigas.pdf.

Gumilow, L. (1996). Od Rusi do Rosji. Szkice z historii etnicznej. Warszawa: PIW.

Hill, F. (2006). Moscow Discovers Soft Power. Current History, 10, 341-347. Retrieved from: http://www.brookings.edu/views/articles/fhill/20061001.pdf.

https://Russkiymir.ru/en/fund/.

http://historyfoundation.ru/about/.

ISCED Fields of Education and Training 2013 (ISCED-F 2013) (2015). Retrieved May 12, 2015 from: http://uis.unesco.org/sites/default/files/documents/international-standard-classification-of-education-fields-of-education-and-training-2013-detailed-fielddescriptions-2015-en.pdf.

Ivakhnyuk, I. (2006). Migration in the Cis Region: Common Problems and Mutual Benefits. International Symposium on International Migration and Development. Population Division. Department of Economic and Social Affairs, United Nations Secretariat, Turin, Italy, June 28-30. Retrieved from: https://citeseerx.ist.psu.edu/viewdoc/downl oad?doi=10.1.1.457.5523\&rep=rep1\&type=pdf.

Krasuski, J. (2007). Europa między Rosją i światem Islamu. Toruń: Wydawnictwo Adam Marszałek. 
Lazari, A. de (1996). Czy Moskwa będzie Trzecim Rzymem? Studia o nacjonalizmie rosyjskim. Katowice: Śląsk.

Lucas, E. (2008). Nowa zimna wojna. Jak Kreml zagraża Rosji i Zachodowi. Poznań: Rebis. Lukyanov, F. (2013, February 1). Why Russia's Soft Power Is Too Soft. Russia in Global Affairs. Retrieved from: http://eng.globalaffairs.ru/redcol/Why-Russias-Soft-PowerIs-Too-Soft-15845.

Łoś, R. (2017). Soft power we wspótczesnych stosunkach międzynarodowych. Łódź: Wydawnictwo Uniwersytetu Łódzkiego.

Miszewski, D. (2012). Percepcja wojny sierpniowej w kulturze masowej. In: R. Potocki, M. Domagała, \& P. Sieradzan (Eds.). Konflikt kaukaski w 2008 r. (pp. 494-501). Warszawa: Europejskie Centrum Analiz Geopolitycznych.

Moczulski, L. (1999). Geopolityka. Potęga w czasie i przestrzeni. Warszawa: Bellona.

Nye, J.S. (1991). Bound to Lead: The Changing Nature of American Power. New York: Basic Books.

Nye, J.S. (2002). The Paradox of American Power: Why the World's Only Superpower Can't Go It Alone. New York: Oxford University Press.

Nye, J.S. (2005). Soft Power: The Means to Success in World Politics. New York: Public Affairs.

Nye, J.S. (2007). Soft Power. Jak osiagnąć sukces w polityce światowej. Warszawa: Wydawnictwa Akademickie i Profesjonalne.

Nye, J.S. (2011). The Future of Power. New York: Public Affairs.

Nye, J.S. (2013, April 29). What China and Russia Don't Get About Soft Power. Foreign Policy. Retrieved from: http://www.foreignpolicy.com/articles/2013/04/29/what_china_and_russia_don_t_get_about_soft_power.

OECD Factbook (2015-2016). Economic, Environmental, and Social Statistics. Retrieved from: https://www.oecd-ilibrary.org/economics/data/oecd-factbook-statistics/ oecd-factbook-2015-2016_39c5fe79-en.

Olszański, T. (2014, September 17). Ukraińskie Partie Polityczne na starcie kampanii wyborczej. Analizy OSW. Warszawa. Retrieved from: https://www.osw.waw.pl/pl/ publikacje/analizy/2014-09-17/ukrainskie-partie-polityczne-na-starcie-kampaniiwyborczej.

O russkom jazykie (2002, August 11). Retrieved from: http://bd.fom.ru/report/cat/cult/ lang_1/k020306.

$O$ russkom jazykie (2006, March 10). Retrieved from: http://bd.fom.ru/report/cat/cult/ lang_1/du06031008.

Podliesnyj, P.T. (2004). Politika SSZA w mieniajuszczemsja mirie. Moskwa: RAN, Nauka. Potocki, R. (2009). Wojna sierpniowa. Warszawa.

Rodkiewicz, W. (2013, February 20). Koncepcja polityki zagranicznej Federacji Rosyjskiej. Retrieved from: https:/www.osw.waw.pl/pl/publikacje/analizy/2013-02-20/koncepcja-polityki-zagranicznej-federacji-rosyjskiej.

Roxburgh, A. (2012). The Strongman: Vladimir Putin and the Struggle for Russia. London: I.B. Tauris.

Seib, Ph.M. (2012). Real-Time Diplomacy: Politics and Power in the Social Media Era. New York: Palgrave-Macmillan. 
Sherr, J. (2013). Hard Diplomacy and Soft Coercion: Russia Influence Abroad. London: Chatham House, Royal Institute of International Affairs.

Sułek, M. (2001) Podstawy potegonomii i potęgometrii. Kielce: Kieleckie Towarzystwo Edukacji Ekonomicznej.

Wierzbowska-Miazga, A., \& Sarna, A. (2014, March 26). Rosyjska presja gospodarcza na Ukrainę. Analizy OSW. Warszawa. Retrieved from: https://www.osw.waw.pl/pl/publikacje/analizy/2014-03-26/rosyjska-presja-gospodarcza-na-ukraine.

Włodkowska, A. (2006). Polityka Federacji Rosyjskiej na obszarze WNP. Toruń: Wydawnictwo Adam Marszałek.

Włodkowska, A. (2008). Problemy rosyjskiej dominacji na obszarze WNP. Rocznik Instytutu Europy Środkowo-wschodniej, 6(1), 65-83.

Włodkowska-Bagan, A. (2012). Soft Power w polityce zagranicznej Federacji Rosyjskiej wobec państw „bliskiej zagranicy”. Kwartalnik Naukowy OAP UW „e-Politikon”, 3, 36-61.

Wojnowski, M. (2015). „Zarządzanie refleksyjne” jako paradygmat rosyjskich operacji informacyjno-psychologicznych w XXI w. Przeglad Bezpieczeństwa Wewnętrznego, $7(12), 11-36$.

Wyciszkiewicz, E. (2003). Wspótczesna Rosja wobec Zachodu. Łódź: Wydawnictwo Naukowe Ibidem.

Yeleyko, I. (2007). Specyfika migracji zarobkowej ludności na Ukrainie. Nierówności Spoteczne a Wzrost Gospodarczy, 11, 401-410. Retrieved from: https://www.ur.edu.pl/ storage/file/core_files/2021/4/23/be3a23be9dd67f335f88bab3a47d8ba0/30.pdf. 